\title{
Review of Pressurized Vessel Structural Design - An Assessment of Total Life
}

\author{
Petr Vosynek ${ }^{1, a}$, Miloš VIk ${ }^{1, b}$, Tomáš Návrat ${ }^{1, c}$ \\ ${ }^{1}$ Institute of Solid Mechanics, Mechatronics and Biomechanics, Brno University of Technology, \\ Technická 2896/2, 616 Brno, Czech Republic \\ avosynek@fme.vutbr.cz, bvlk@fme.vutbr.cz cnavrat@fme.vutbr.cz
}

Keywords: pressurized vessel, total life, fatigue, fracture.

\begin{abstract}
The paper discusses life prediction of pressurized cylindrical container because of its dangerous failure during usage. The fatigue of material and crack propagation were obvious from the fracture surface. Crack initiation was located in the notch root of the thread. Our goal was to review the vessel structural design based on its technical documentation.

Two approaches for estimating the crack initiation period were used. As input parameters, stressstrain relations in the notch were obtained from FEM analysis, done in ANSYS Workbench. The first approach makes use of Neuber's rule based on elastic-plastic shakedown and cyclic stressstrain curve. The second concept (which is described in ČSN EN 13445-3 or AD 2000 Mekblatt S2 respectively) uses elastic shakedown. Included stress-life curves leads to the number of cycles to crack initiation.

Finally the subcritical crack growth period and final fracture were estimated $=$ the total life was evaluated.
\end{abstract}

\section{Introduction}

Bolted joints are the most widely used nonpermanent joints in the mechanical engineering industry design. They are not used only in a classic design (bolt and nut), but also in less common structural junctions, or in specially adapted nuts and bolts. In such cases, there is a need for a complex stress-strain analysis of the whole assembly. That means not using general conclusions from the standard bolt and nut connection (e.g. critical area is located in the first thread of the bolt under the nut; using a nominal approach for working on limit states such life) [1].

The centre of our interest is a pressurized vessel which its construction, material selection, manufacturing, security systems and documentation filed under ČSN EN 14359 standard [2]. If the number of changes of pressure (from maximum to minimum) is greater than 500 (which is our case), it is necessary to use chapters 17 or 18 of ČSN EN 13445-3 [3] for fatigue assessment. Chapter 18 is preferred because of its more detailed life assessment. The standard [3] is very similar to AD 2000 Merkblatt S2 [4].

The standard [3] is based on local elastic (or simplified elastic-plastic) stress and evaluates the number of cycles to crack initiation $(0.5 \mathrm{~mm}-1 \mathrm{~mm})$.

More general approach to estimate the number of cycles to crack initiation was done by combination of Neuber's rule based on elastic-plastic shakedown and cyclic stress-strain curve.

The propagation period was also evaluated because of vessel fracture. Which give finally the total life.

\section{Materials and methods}

Stress strain analysis. Computational model is composed of several sub models. 1) Model of material is given in the documentation and relates to SA 372 Grade E Class 70 [5], tensile strength $\mathrm{R}_{\mathrm{m}}=825 \mathrm{MPa}$, yield strength (minimum) $\mathrm{R}_{\mathrm{p} 0.2}=458 \mathrm{MPa}$, ductility $18 \%$, hardness 248 $\mathrm{HB}$, Young's modulus $\mathrm{E}=210 \mathrm{GPa}$, Poisson's ratio 0.3. 2) Model of geometry has 2D axisymmetric configuration as it is in threated component usual, see Fig. 1. The diameter "d" corresponds to the thread M 375x4 and (D-d)/2=28 mm. 3) Model of boundary condition and 
interaction: internal pressure ("p"), normal zero displacement (dashed line), and nonlinear contact between bodies (friction coefficient $\mathrm{f}=0.15$ ) is located between threads and surroundings. The general size of the finite elements was set to $2.5 \mathrm{~mm}$ and in the area of interest (thread groove) to $0.05 \mathrm{~mm}$.

For the assessment of subcritical crack growth bending stress and membrane stress are needed. From FEM outputs we get 'total stress' - which is sum of peak, membrane, and bending stress. Decomposition was done by stress linearization in the ANSYS (help reference [6]) and according to FITNET [7].

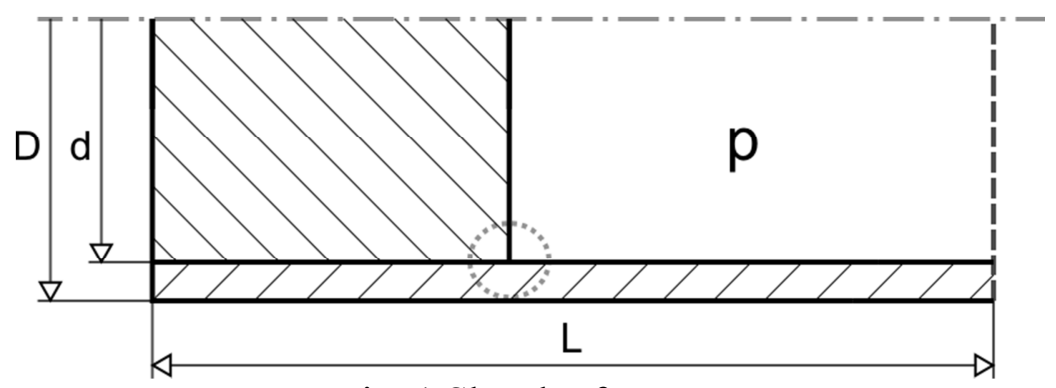

Fig. 1 Sketch of geometry

Crack initiation period - general approach. Another material characteristic (cyclic stressstrain curve) was estimated using the work presented by Bäumel and Seeger [8] and additionally by Klesnil [9].

In the investigated area, we assumed uniaxial loading because of small contribution of the second principal stress, and zero contribution of third principal stress - plane stress condition ( $\mathrm{R}=0.3$; more detail of stress state is presented in chapter Results and discussion). This assumption leads to more conservative life prediction.

Because the stress comes from the linear FEM analysis, we are indexing them as " $\mathrm{H}$ " for "Hooke's stress" (terminology it this case is still not stable, e.g. in ČSN EN 13445 are called pseudo-elastics stress).

The upper Hooke's stress is higher than yield strength $\sigma_{\mathrm{hH}}>R_{\mathrm{p} 0,2}$ but also suits the assumption for elastic shakedown effect $\Delta \sigma_{\mathrm{H}}<2 R_{\mathrm{p} 0,2}$.

Evaluation of the cyclic stress-strain relations in the critical area was done by Neuber's rule [10].

Next step was evaluating the number of cycles to crack initiation. Several concepts (strain-life and stress-life) were used with consideration of the influence of the mean stress. "Morrow" - no mean stress correction [11]:

$$
\varepsilon_{\mathrm{at}}=\varepsilon_{\mathrm{f}}^{\prime}(2 N)^{c}+\frac{\sigma_{\mathrm{f}}^{\prime}}{E}(2 N)^{b}
$$

“mod. Morrow" [11]:

$$
\varepsilon_{\mathrm{at}}=\varepsilon_{\mathrm{f}}^{\prime}(2 N)^{c}+\frac{\left(\sigma_{\mathrm{f}}^{\prime}-\sigma_{\mathrm{m}}\right)}{E}(2 N)^{b} .
$$

"Ma-Co-Ba" - Manson-Coffin-Basquin [12]:

$$
\frac{\Delta \sigma}{2}=\sigma_{\mathrm{a}}=\sigma_{\mathrm{f}}^{\prime}(2 N)^{b} .
$$

"Mo-La" - Morrow-Landgraf [13]: 


$$
\frac{\Delta \sigma}{2}=\sigma_{\mathrm{a}}=\left(\sigma_{\mathrm{f}}^{\prime}-\sigma_{\mathrm{m}}\right)(2 N)^{b}
$$

And finally the "SWT"-Smith-Watson-Topper [14]:

$$
\sigma_{\mathrm{h}} \varepsilon_{\mathrm{at}}=\frac{\left(\sigma_{\mathrm{f}}^{\prime}\right)^{2}}{E}(2 N)^{2 b}+\sigma_{\mathrm{f}}^{\prime} \varepsilon_{\mathrm{f}}^{\prime}(2 N)^{b+c}
$$

Crack initiation period - standard [3]. Overall assessment is based on a linear elastic stress (Hooke's stress) with application of the relevant coefficient factors. The basic equation (6) compares amplitude of Hooke's stress with fatigue strength of the specimen without notch, while considering influence of surface roughness $-f_{s}$, size of the component (thickness of the wall) $-f_{e}$, mean stress $-\mathrm{f}_{\mathrm{m}}$ and temperature $-\mathrm{f}_{\mathrm{T}}$ :

$$
\Delta \sigma_{\mathrm{H}} \leq \Delta \sigma_{\mathrm{N}}^{\mathrm{x}}
$$

$$
\Delta \sigma_{\mathrm{N}}^{\mathrm{x}}=\Delta \sigma_{\mathrm{N}} f_{\mathrm{s}} f_{\mathrm{e}} f_{\mathrm{m}} f_{\mathrm{T}}=\Delta \sigma_{\mathrm{N}} f_{\mathrm{u}}
$$

In our case

$$
\Delta \sigma_{\mathrm{N}}<\left(\Delta \sigma_{\mathrm{N}}\right)_{2 E 6}
$$

therefore

$$
N=\left(\frac{2.69 R_{\mathrm{m}}+89.72}{\frac{\Delta \sigma_{\mathrm{H}} \cdot k_{\mathrm{e}}}{f_{\mathrm{u}}}}\right)^{10} .
$$

Subcritical crack growth. The fatigue crack growth under cyclic loading is described by ParisErdogan's law (e.g. [15]):

$$
\frac{d a}{d N}=C\left(\Delta K_{I}\right)^{m}
$$

The stress intensity amplitude is given in our case by equation:

$\Delta K_{I}=\left(\Delta \sigma_{\mathrm{m}} M_{\mathrm{m}}+\Delta \sigma_{\mathrm{b}} M_{\mathrm{b}}\right) \sqrt{\pi a}$.

Where $M_{m}$ and $M_{b}$ describe calibration coefficient and were taken from [16]. Calibration coefficients are a function of crack length and were integrated numerically (the differentials changes to differences). The increase of cycle for a small increment of length of the crack:

$$
\Delta N=\frac{\Delta a}{C\left[\left(\Delta \sigma_{\mathrm{m}} M_{\mathrm{m}}+\Delta \sigma_{\mathrm{b}} M_{\mathrm{b}}\right) \sqrt{\pi a}\right]^{m}} .
$$

There is a complication cause by the fatigue crack growing from the root of the thread notch which has depth $\mathrm{h}=0.289 \mathrm{~mm}$. We respect this by using an effective crack length according to [17]: $\mathrm{a}_{\mathrm{ef}}=\mathrm{a}+\mathrm{h}$. All necessary coefficients were taken from [16]. 
Fracture diagram - critical crack length. Fracture assessment was made by means of a failure assessment diagram (FAD). We apply two forms of this diagram: a) according to the methodology R-6 [16]:

$$
K_{\mathrm{r}}=\left(1-0.14 L_{\mathrm{r}}^{2}\right)\left[0.3+0.7 \exp \left(-0.65 L_{\mathrm{r}}^{6}\right)\right] \text {. }
$$

b) According to the FITNET [7]:

$$
K_{\mathrm{r}}=\frac{0.3+0.7 \exp \left(-0.6 L_{\mathrm{r}}^{6}\right)}{\sqrt{1+\frac{1}{2} L_{\mathrm{r}}^{2}}}
$$

\section{Results and discussion}

The inner pressure cycle is given by the ratio $r=0.567$ (repeated cycle). The extreme stresses arise in the first row of the thread on both sides of connection Fig. 1 - dotted circle. On plug side the thread radius is $\mathrm{R}=0.577 \mathrm{~mm}$ and on the wall side it is $\mathrm{r}=0.289 \mathrm{~mm}$.

Because of the different toughness, compared to classical bolt and nut combination, the higher stress is located rather on the wall than on the plug, and will proceed to fatigue analysis. Stress state corresponds to plane stress condition (third principal stress is equal to zero). The first principal stress is equal to $1415 \mathrm{MPa}$. The ratio between the second principal stress and the first principal stress is known as biaxiality ratio, and in our case it is equal to value 0.3 .

In the general approach to fatigue analysis the most common criterion is "SWT" prediction. The number of cycles to crack initiation (from 0.5 to $1 \mathrm{~mm}$ length) is $\mathrm{N}_{\mathrm{SWT}}=116 \cdot 10^{3}$. The other concepts are relative to the "SWT": "Morrow" $\mathrm{N}=67 \cdot \mathrm{N}_{\mathrm{SWT}}$, "mod. Morrow" $\mathrm{N}=3.1 \cdot \mathrm{N}_{\mathrm{SWT}}$, "MaCo-Ba" $\mathrm{N}=67 \cdot \mathrm{N}_{\mathrm{SWT}}$, "Mo-La" $\mathrm{N}=0.9 \cdot \mathrm{N}_{\mathrm{SWT}}$. So far there is no recommendation of suggestion which criterion should be preferred.

From the fatigue assessment [3] finally described by equation (9) we obtain $\mathrm{N}=26 \cdot 10^{3}$ cycles. But it is necessary to also take into account the safety coefficient $\mathrm{n}_{\mathrm{N}}$ according to paragraph 18.11.3 from [3]. In common engineering structures, the probability of the crack initiation is usually considered to be 0.05 . Therefore, the corrected number of cycles could be evaluated as $\mathrm{N}_{\text {corr }}=4.7 \cdot \mathrm{N}=122 \cdot 10^{3}$.

When taking advantage of information about reliability (0.95) of survival, the result surprisingly well corresponds to the first approach.

From the subcritical crack growth criteria we get the critical crack length equal to $a_{K R}=14 \mathrm{~mm}$ and the propagation life to fracture $\mathrm{N}_{\mathrm{p}}=210 \cdot 10^{3}$, with reliability 0.95 . The total number of cycles to fracture $\mathrm{N}_{\text {tot }}=\mathrm{N}+\mathrm{N}_{\mathrm{p}}=332 \cdot 10^{3}$.

\section{Conclusion}

The complex review of the pressurised vessel design with total life assessment was done. Stressstrain analysis proves the need for complex solution of stress-strain states in whole assembly to determine the critical area in threated construction which differs from classical bolt nut group.

Even if the general approach is used for predicting the number of cycles leading to crack initiation, it is clear that the design does not match the requirement of infinite life ( $\mathrm{N}>10^{6}$ cycles).

Future work will be aimed on comparing the numerical solution of the crack propagation presented by Kubik [18, 19], against the analytical approach presented in this paper.

\section{Acknowledgement}

This work is an output of research and scientific activities of NETME Centre, regional R\&D centre built with the financial support from the Operational Programme Research and Development for 
Innovations within the project NETME Centre (New Technologies for Mechanical Engineering), Reg. No.CZ.1.05/2.1.00/01.0002 and, in the follow-up sustainability stage, supported through NETME CENTRE PLUS (LO1202) by financial means from the Ministry of Education, Youth and Sports under the „National Sustainability Programme I“.

\section{References}

[1] R. Schneider, U. Wuttke, C. Berger, Fatigue analysis of threaded connections using the local strain approach, Procedia Engineering, Volume 2, Issue 1, April 2010, Pages 2357-2366, ISSN 1877-7058, http://dx.doi.org/10.1016/j.proeng.2010.03.252.

[2] ČSN EN 14359 (69 8259): 2012 - Gas-loaded accumulators for fluid power applications (in Czech)

[3] ČSN EN 13 445-3 (69 5245): 2010 Unfired pressure vessels - Part 3: Design (in Czech)

[4] AD 2000 Merkblatt S 2 Technical rule, 2004-10 - Analysis for cyclic loading

[5] ASME Boiler and Pressure Vessel Code Section II: Materials

[6] J. L. Gordon. "OUTCUR: An Automated Evaluation of Two-Dimensional Finite Element Stresses" according to ASME. Paper No. 76-WA/PVP-16. ASME Winter Annual Meeting. December 1976

[7] M. Kocak, et al., FITNET European Fitness-for-Service Network: Fracture - Fatigue Creep - Corrosion. 2008

[8] A. Bäumel, T. Seeger, Material Data for Cyclic Loading - Suppl. 1. Materials Science Monographs 61, Elsevier Sc. Publisher, Amsterdam 1990

[9] M. Klesnil, P. Lukáš, Únava kovových materiálů při mechanickém namáhání, Academia, Praha 1975

[10]H. Neuber, Über die Berücksichtigung der Spannungskonzentration bei Festigkeitsberechnung. Konstruktion, Vol. 20, 1968, No. 7, pp. 245-251

[11]Y. L Lee, H. T. Kang, Metal Fatigue Analysis Handbook: Practical Problem-Solving Techniques for Computer-Aided Enegineering. Elsevier, Amsterdam 2012

[12] S. S. Manson, G. R. Halford, Fatigue and Durability of Structural Materials. ASM International, 2006

[13] SAE Fatigue Design Handbook. Third Edition, Society of Automotive Engineers 1997

[14]K. N. Smith, P. Watson, T. H. Topper, A Stress-Strain Function for the Fatigue of Metals. Journal of Materials, 5, 1970, No. 4, pp. 767-778

[15]D. Broek, The Practical Use of Fracture Mechanics. Kluwer Academic Publishers, 1989

[16] British Standard BS 7910: Guide to Methods for Assessing the Acceptability of Flaws in Metallic Structures. 2005

[17]R. A. Smith, K. J. Miller, Fatigue cracks at notches. International Journal of Mechanical Sciences, Vol. 19, 1977, No. 1, pp. 11-22

[18]P. Kubík, F. Šebek, J. Petruška, J. Hůlka, F. Šebek, Ductile Fracture Criteria in Prediction of Chevron Cracks, 2013, Advanced Materials Research, 716, pp. 653-658.

[19]P. Kubík, F. Šebek, J. Petruška, J. Hůlka, J. Růžička, M. Španiel, J. Džugan, A. Prantl, Calibration of Selected Ductile Fracture Criteria Using Two Types of Specimens, 2014, Key Engineering Materials, 592-593, pp. 258-261 